\title{
自動車組立ラインのウィンドウ搭載支援ロボット
}

\author{
村 山 英 之*1 武 居 直 行*2 松 本 邦 保*1 \\ 鴻 巣 仁 司 $* 1$ 藤 本 英 雄 $* 3$
}

\section{Development of a Car Window Installation Assist Robot}

\author{
Hideyuki Murayama*1, Naoyuki Takesue ${ }^{* 2}$, Kuniyasu Matsumoto*1, \\ Hitoshi Konosu*1 and Hideo Fujimoto*3
}

\begin{abstract}
Traditionally, robots and humans work independently, isolated from each other for safety reasons. We developed a robot for use on the assembly line which works together with a human operator, assisting and augmenting the operator's skills. Because of its function, this robot is known as the "Car Window Installation Assist Robot" and is currently in use on the plant of Toyota Motor Corporation.

In this paper, we propose a method to estimate human intent as well as a skill assist control method. Moreover, we present technology that enables safe human-robot cooperation, high product quality, and the cycle time of only 48 seconds.
\end{abstract}

Key Words: Robot, Skill Assist, Human Intent, Window Installation

\section{1.はじめに}

工場では産業用ロボットによる自動化が進められている。一 方, 自動車の最終組立工程では, 人手による作業が多く残って いる，その組立工程の一つに，ウィンドウ搭載作業がある。こ の工程は従来, Fig. 1 のように, ウィンドウガラスを左右から 二人で把持し，コンベアで搬送されている車体に搭載していた。 10〜15 $[\mathrm{kg}]$ 程度あるウィンドウガラスの重量による負担は, 通常，空気圧アクチュエータやスプリングバランサにより軽隇 されているため問題となることは少ない。しかし, ウィンドウ ガラスには車体に掛けるためのストッパが固定されているため, 決まった向きで隙間に挿入する必要があり，その挿入位置の要 求精度は高い。また、リアウインドウの場合（Fig. 1) は，トラ ンクが開いた状態で，車体とトランクの間をガラスがぶつから ないように通す必要がある。 そのため, ウインドウ搭載作業は, 人手作業の中でも技能と熟練が必要であり，習熟に時間を要す、 また二人の相性が合わない場合は作業がスムーズに進まない．

最終組立工程の人手による作業の問題に対して，トヨタでは 1980 年代に無人の自動化を推進したが，生産効率が悪化し多く

原稿受付 2009 年 7 月 28 日

*1 トヨ夕自動車株式会社

$* 2$ 公立大学法人首都大学東京

*3国立大学法人名古屋工業大学

${ }^{* 1}$ Toyota Motor Corporation

${ }^{* 2}$ Tokyo Metropolitan University

${ }^{* 3}$ Nagoya Institute of Technology

口本論文は有用性で評価されました。

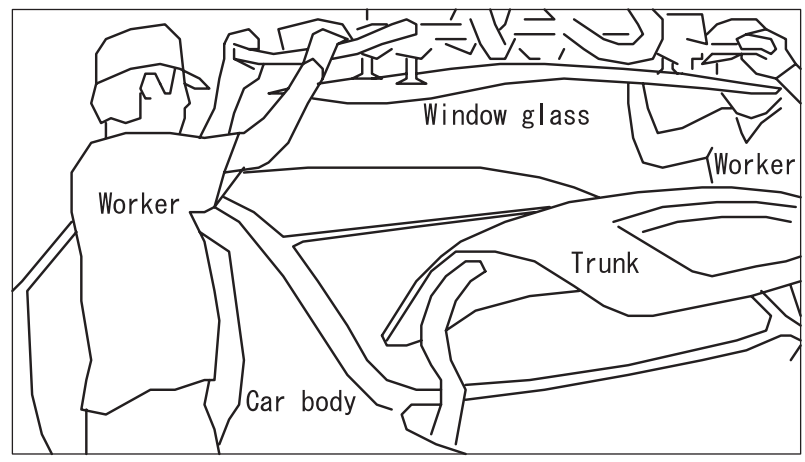

Fig. 1 2-person car window installation

をとりやめた，その原因は次のように考えられる。

（1）ワーク位置認識の精度と, 信頼性の低さから来る製品の 品質低下・設備の不具合多発。

（2）位置認識のため，ボデイを止めるかすくい上げるなど工 程が延び，大スペースが必要。

（3）設備が大型化・複雑化し高コスト.

（4）複雑な設備の保全に高度なスキルが必要.

こうした，人を排除した従来の自動化では，グローバル展開 に求められる車種変更と生産能力増強への迅速でフレキシブル な対応が難しい [1]. そこで, 我々が目指したあるべき姿は,「最 終的な品質は人が確認し，機械が人と共存して作業を支援する 『協働』化」である。

これを踏まえ，人と安全に共存できるロボットと技能支援技 術を開発し, 高価な認識機能は最小限にとどめて, シンプル。 
スリム化を図る。そして，ボデイを搬送する従来ど㧍りの工程 に扔いて，人の技能を活かした片側一人でのウィンドウ搭載を 実現することを開発の狙いとした，本稿ではこうして開発・実 用化したウィンドウ搭載支援装置 “ウィンドウ搭載アシスト”に ついて報告する. 以下に構成を示す. 次の第 2 章で従来技術に ついてまとめ, 本研究開発の課題について述べる. 第 3 章では, 人との安全な共存を実現するための基本方針および実現項目に ついて示す，第 4 章において, 手ぶれの影響を低減する進行方 向ガイドを提案し, その効果を実験により確認するとともに量 産ラインでの実作業について示す。第 5 章で本論文をまとめ, 第 6 章で今後の展開について述べる.

\section{2. 従来技術および本対象作業}

本章では，従来技術について示すとともに，対象とするウィ ンドウ搭載作業の手順㧍よび課題・要求仕様について述べる.

\section{1 従来のパワーアシスト技術}

人とロボットが同じ作業領域や対象物などを共有し, 協調作業 を行う人間機械協調系の研究は近年盛んに行われている [1]〜 [16]. 人の技能・判断能力や適応性が必要とされる作業において， 口 ボットによりパワーや精密さを付加することで，人の身体的・ 精神的負担を軽減したり，作業性能や製品の品質を向上したり することができると期待されている.

例えば, 移動軌道や到達目標点が既定されている場合には, 車 輪の操舵やCVTにより作業に適した仮想面を実現する cobot [5] や Virtual Fixture と呼ばれる仮想的なガイドを設けることで 作業を容易にすることができる [6]～[8]. 本研究で対象とする作 業では, 組付位置は扮㧍よそ決まっているため, 組付位置近傍 まではガイドできるが, 最終位置は作業者の判断によって決ま る。そのため，上記の手法をそのまま用いることはできない．

協調ロボットの研究の多くは, 人の操作力を力覚センサで検 出し, その力覚情報をもとにロボットの機械インピーダンスを 制御 [17] [18] する手法を用いている. しかし, 固定した慣性・粘 性のインピーダンスでは操作者の操作感と作業性能の両立が難 しいため, 異方性を持たせたり可変にしたりすることで, 操作性 を向上する研究が行われている，例えば，車輪特性を制御により 実現することで, 長尺物の協調搬送を容易にする手法 [9] や, 複 数台ロボットにおいてキャスターの機械特性を再現することで, 人とロボット群が扔互いの情報を通信することなく, 協調動作を 実現する手法 [10] が提案されている，また，作業フェーズ，時 間, 操作力などによってインピーダンスを変化する手法 [1] [11]〜 [15] が提案されている.

その一部はすでに組立工場などで実用化されている [1] [16]. そ の実用化されている技術の一つである, 自動車のインストルメン トパネルモジュール (インパネ) の搭載用スキルアシスト [1] [14] では, カセンサで計測した操作力に基づき, 仮想インピーダン ス特性（質量・粘性など）を持つように，アシスト力を発生させ るインピーダンス制御を用いている。 これにより, 質量 $50[\mathrm{~kg}]$ 超で慣性の大きいインパネを, 軽く動かすことができる。 また, 可変インピーダンスにより, 操作感と位置決め性能も向上して いる.

しかし, インパネ搭載の要求精度は左右 $\pm 5[\mathrm{~mm}]$, 上下

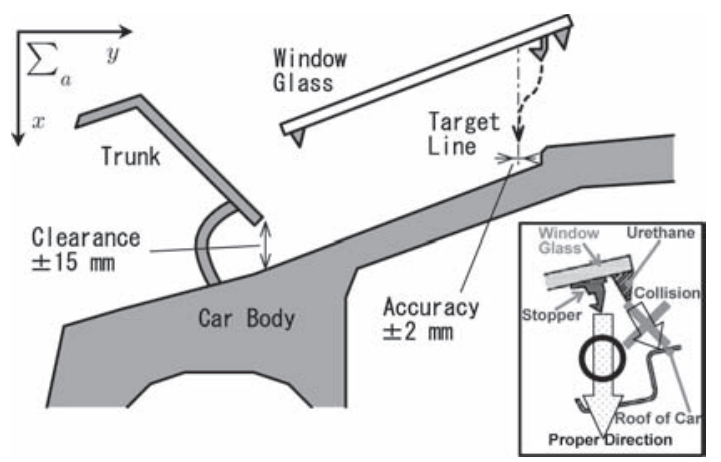

Fig. 2 Schematic of window installation task

$\pm 15[\mathrm{~mm}]$ で, 高精度位置決めを支援するガイド機能はない． また，ボデイが搬送される前後方向には，止まるところまで押 し込んで行けばよいので精度要求はない。 これに対し, ウィン ドウ搭載の場合には，接着剤があるためやり直しがきかない上 に，ボデイ搬送方向である前後方向は，動きながらの位置合わ せが要求され, 前後 $\pm 2[\mathrm{~mm}]$, 左右 $\pm 4.5[\mathrm{~mm}]$ と非常に厳し

く, 従来の技術ではその要求精度を満たすことが難しい.

\section{2 ウィンドウ搭載作業}

対象となるウィンドウ搭載作業（Fig. 2）は，以下のような 作業手順（1）（3）で進められる，また，それぞれの手順にお いて要求される仕様を下に併記する。

（1）接着剂が付着しないように, 離れた上空で車体の前後方 向におけるガラスの位置を合わせる。

(a) コンベアで搬送されて動いている車体に搭載する.

(b) トランクーボデイ間の $\pm 15[\mathrm{~mm}]$ の隙間にガラスを ぶつけずに通す。

（c）接着剂のウレタンを，外から見えて意匠上問題とな る場所に付着させない.

（2）車体の前後方向の位置がずれないようにガラスを真下に まっすぐ降ろす。

（a）ガラスを位置決めするウインドウストッパを，決まっ た向きでボデイ孔に挿入しなくてはならない.

（b）挿入位置の要求精度が $\pm 2[\mathrm{~mm}]$ と高精度である.

（3）ウィンドウストッパをボデイ孔にはめ込む.

(a) 一度接着するとやり直せない.

(b) 最大 $800[\mathrm{~N}]$ 程度でガラスを押し付けて, 車体に接 着剂を密着させる。

(c) サイクルタイム $48[\mathrm{~s}]$ のうち, 許容作業時間 $7[\mathrm{~s}]$ 内 に完了する。

ガラスをぶつけずに運んだり, 接着剤が組付箇所以外に付着 したりしないように，ガラスを組付位置近傍の上空まで誘導す ることは, 従来技術でも可能である。 しかし, 短時間に最終挿 入位置まで進路を修正しながら，ぶれずに挿入し，はめ込むた めのアシスト技術が必要となる。

\section{3. 人との安全な共存}

本章では, 前章の要求仕様を満たすアシスト技術とともに重 要な, 人と協㗢するロボットとしての安全性について述べる。 


\section{1 安全に共存する基本方針}

リスクアセスメントに基づくリスク低減対策は法制化されて いる，機械に関しては，厚生労働省基発第 0731001 号「機械の 包括的な安全基準に関する指針」で，すべての機械に適用できる 包括的な安全確保の方策に関する基準が示されている [19] [20].

この指針に扔いて，「適切なリスクの低減が達成されていない と判断した危険性又は有害性について, 次に揭げる優先順位に より，機械に係わる保護方策を検討し実施するものとする.」と されている，第 1 に、リスクを除去，低隇する「本質的安全設 計方策」, 第 2 に「安全防護（隔離などを含む）による付加保護 方策」, そして, それでも残る「残留リスクを労働者に伝えるた めの作業手順の整備, 労働者教育の実施等を行う」である.

指針の別表第 2 に規定される本質的安全設計方策の一つとし て,「激突されたときに，身体に被害が生じない程度に運動エネ ルギーを小さくすること」があげられている，これに基づき，低 出力モー夕での駆動技術を開発し，本質的安全設計方策を図る。 その上で,リスクアセスメントに基づき, 残留リスクを受け入 れ可能なレベルに下げるため, 衝突を検出するバンパスイッチ, 最高速度制限などの付加保護方策を実施した。

\section{2 低出力駆動の目標值}

産業用ロボットの可動範囲内での人の操作には, 労働安全衛 生法や労働安全衛生規則による厳しい規定がある. しかし, 次 に示す, 厚生労働省告示「労働安全衛生規則第三十六条第三十 一号の規定に基づき厚生労働大臣が定める機械を定める告示」 に規定されるように，原動機の定格出力が $80[\mathrm{~W}]$ 以下であれ ば，危険性が少ない出力であるとして除外されている [21].

「定格出力（駆動用原動機を二以上有するものにあつては，そ れぞれの定格出力のうち最大のもの）が八○ワット以下の駆動 用原動機を有する機械」

これに基づき，本質的安全設計方策として，すべての駆動軸の モータの定格出力を各軸 $80[\mathrm{~W}]$ 以下にすることを目標とした.

\section{3 接着剂押しつぶし機能}

片側一人作業では，反対側は人がガラスを押せないため，人 手では接着剤のウレタンをつぶして車体に密着させられない. 押しつぶしが不十分だと，雨漏れの品質不良の原因となる。

この押し込み力は, ガラスサイズや接着剤の種類（硬さ）に もよるが, 約 $800[\mathrm{~N}]$ が必要となる。 このうち, $10 〜 15[\mathrm{~kg}]$ 程 度あるガラスと装置手先部の重力で $500[\mathrm{~N}]$ 程度は負担できる が, 残り約 300 [N] は装置の推力で押す必要がある.

\section{4 低出力モータによる押し込み機能の実現}

これに対し, 市販の $80[\mathrm{~W}]$ モータ使用の垂直多関節ロボット では, 「推力不足」と「上下方向の動作範囲不足」の問題がある

(Fig. 3). 推力不足の理由として, 以下が考えられる.

・リンクが直列に結合されたシリアルリンク構造で, 負荷を 各軸で分担できない.

- 軽量部品の高速搬送・組立に特化して, 高速性を重視し, 駆 動軸の減速比が低い.

また，動作範囲不足を解消するために，リンクを伸ばすと次 の問題が生じる.

・推力がさらに低下する.

・手先の慣性質量が増加し加減速が遅い.

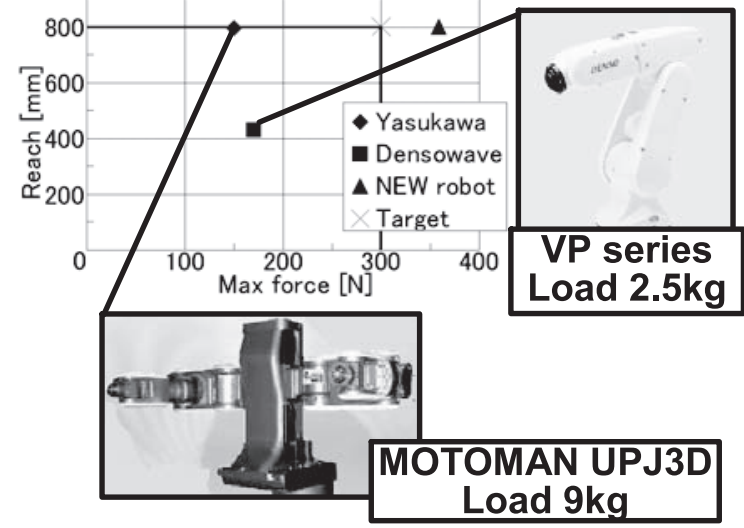

Fig. 3 Robot force comparison

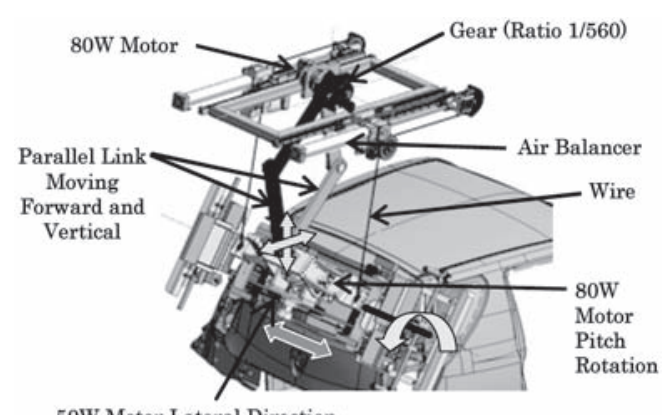

Fig. 4 Mechanical structure

そこで, 低出力の $80[\mathrm{~W}]$ モータで高推力が出せる，次のよう な機構（Fig.4）を採用した。

（1）平行リンク機構により，各駆動軸に負荷トルクを分散さ せ，合計推力を向上させた.

（2）上記により，慣性質量の大きいモータをリンク根元部に 集約. 加減速時の負荷トルクを低減し, 短時間での加減 速を実現した。

（3）直動機構に比へ，折りたたみ時の上下方向のスペースが 小さくでき，高さに余裕のない既存工場にも適用可能と なり, 沉用性が向上.

（4）機構解析により, 必要な推力と作業速度を出せるよう, リ ンク姿勢と減速比を最適化.

（5）ウィンドウガラスを吸着する四つのパッドのロードセル で，押し込み力を計測する。

これにより, 各軸 $80[\mathrm{~W}]$ 以下で, サイクルタイム $48[\mathrm{~s}]$ （従来 の二人作業ではサイクルタイムが $60[\mathrm{~s}]$ だった）と推力 $300[\mathrm{~N}]$ を両立することができた，そして，押し込み力のフィードバッ ク制御により，ガラス全面に対して均一な押し込み力制御を実 現し，接着剤の押しつぶし品質を確保した。

\section{5 産業用ロボット ISO 規格と安全対策}

産業用ロボットの ISO 規格 ISO10218-1:2006 の 5.10 節にお いて，人とロボットが協働作業する際の要件「協働運転要求事 項」が規定されている [23]. 本節では, 本装置のこの要件の準 拠状況と安全対策について説明する。

ISO 規格の協働運転要求事項では, 大きく分けて次の五つの 
規定のどれかを満たすことが求められている.

（1）協働作業空間内で人体を検知したら停止する.

（2）手の位置を検知, かつ, 速度 $250[\mathrm{~mm} / \mathrm{s}]$ 以下.

（3）オペレータとの安全距離が確保できなければ保護停止, かつ, 速度 $250[\mathrm{~mm} / \mathrm{s}]$ 以下.

（4）設計による推力もしくは動力の制限. 合計最大 $150[\mathrm{~N}]$ 以下，または，合計最大 $80[\mathrm{~W}]$ 以下.

（5）制御による推力もしくは動力の制限．合計最大 $150[\mathrm{~N}]$ 以下，または，合計最大 $80[\mathrm{~W}]$ 以下.

現状では, 国内法規と産業用ロボットの ISO 規格が整合して いない. 国内法規で求められる各軸定格 80 [W] 以下の規定と, ISO で規定される速度, 推力, 動力の制限值を同時に満たそう とすると, 非常に速度が遅くなったり, ワークを持ち上げるだ けの推力が出せず, 産業現場のサイクルタイムや, 接着剤押し つぶしなどに見られるような推力の必要な機能要求に応えるこ とが物理的に困難である.

このため, 日本国内では ISO 規格は任意規格であり，法規の 遵守が優先されることを考慮し, 本装置では国内法規の遵守を 優先し, ISO 規格に準拠できない項目は別の安全対策で安全を 確保した．以下で各動作モードの準拠状況を説明する.

(1) 搭載までのアシスト動作時. デッドマンスイッチを押し ながら操作し, 速度 $250[\mathrm{~mm} / \mathrm{s}]$. 以下の制限をかけてお り, 先の（2）の ISO 規格を満たしている。

(2) 接着片押しつぶし $\Rightarrow$ 上昇動作時. 作業者が押しつぶし 動作開始のスイッチを押したあとは，自動で押し込み $\Rightarrow$ 完了 $\Rightarrow$ 上昇動作が行われるため，先の ISO 規格の（2） は準拠できない.

また，接着剤の押しつぶしに推力が必要であるため, 合計推 力 $150[\mathrm{~N}]$ もしくは合計動力 $80[\mathrm{~W}]$ の制限を満たせていない. このため, 先の ISO 規格の（4），(5）にも準拠できていないが, 設定した押しつぶし力を大きく超える異常な押し込み力を, 吸 着パッドに設けたロードセルが検知した場合には停止する。ま た，速度は $250[\mathrm{~mm} / \mathrm{s}]$ 以下に制限をかけている。ささらに，バ ンパスイッチでの衝突の検知と, 非常停止スイッチを左右両側 に設け，作業者が危険を感じたら，これを押して止めることで 対応している.

速度の制限については, 次のような方式をとることで, ISO13849-1:1999 で規定される安全カテゴリー 3 に準拠する システム構成となっている [24].

（1）指令速度を $250[\mathrm{~mm} / \mathrm{s}]$ 以下にソフトウェアで制限する.

（2）サーボモータ内蔵とは別のロータリーエンコーダで速度 を計測し，アシスト制御の制御機器とは別の制御機器で 手先速度を演算し, 常時監視を行う 2 重系を構成してい る。実測速度が $250[\mathrm{~mm} / \mathrm{s}]$ を越えた場合には, サーボ モータのパワーラインを遮断する回路構成としている.

\section{4. 組付位置決め精度と操作性の両立}

\section{1 現状の位置合わせの課題}

インパネ搭載スキルアシスト [1] [14] では, 作業フェーズに よって慣性と粘性を変える可変インピーダンス制御により位置 決め精度と操作感の向上が図られている。本ウィンドウ搭載作
業ではインパネ搭載作業ほど長いストロークを搬送しないため, フェーズの判別が難しい場合がある. 操作力依存可変ダンピン グ制御 [15] は, 次式のように, 操作力の大きさに応じて粘性を 可変にすることで, フェーズ判別がなく, 簡便ながらも同様の 効果が得られる。

$$
D\left(F_{h}\right)=D_{0} \frac{A}{\left|F_{h}\right|+A}
$$

ここで, $D\left(F_{h}\right)$ は粘性係数, $D_{0}$ は基準粘性係数 (定数), $A$ は 粘性可変感度 (定数), $F_{h}$ は操作力である.

そこで, この操作力依存可変ダンピング制御を導入し, 次式 の仮想インピーダンスを実装した.

$$
M \ddot{p}+D\left(F_{h}\right) \dot{p}+F\left(\dot{p}, F_{h}\right)=F_{h}
$$

ここで, $M$ は質量, $p$ は位置, $F$ は摩擦力である.

しかし, 上記手法は, 位置決めや操作性の向上に有効ではあ るが, $\pm 2[\mathrm{~mm}]$ の精度でストッパを車体の孔に挿入するには不 十分である、従来のアシスト制御では, 基本的に操作力の向き にガラスが進むように制御しているため，人の手ぶれによりまっ すぐに進まずずれてしまう。そうすすと，ボディのルーフ部に ガラスが接触して (Fig. 2 の右下枠を参照), 接着剤が付着し意 匠上の問題が発生するほか, 接着剤の一部が欠き取られて雨漏 れの原因になる。

挿入位置上空において, まっすぐ降ろしたいのであれば, 真 下向きにしか動かないようにガイド制御で拘束すればよい.し かし，挿入位置を調節する際，前後に動かしにくく位置合わせ がしにくくなる。このため, ガイド制御のあり・なしの切り替 えが必要になる。人がスイッチで切り替えるとわずらわしく操 作性が低下し，またサイクルタイム $48[\mathrm{~s}]$ のうち許される搭載 作業時間 $7[\mathrm{~s}]$ 間での完了が難しいため, この方法は作業者に受 け入れられない.

\section{2 操作力方向による進行方向ガイド制御による技能支援} そこで, 2.2 節の作業手順（1）と（2）の人の操作意困を判 別して，ガイド制御の有無を自動的に切り替えることを考える.

Fig. 5 に人がまっすぐ動かそうとしたときの位置ずれと操作 力の向き（目標の方向を $0[\mathrm{deg}]$ とする）の計測結果を示す.な お, 仮想インピーダンス特性の設定は, 質量 $M=20[\mathrm{~kg}]$, 基準 粘性係数 $D_{0}=80[\mathrm{~N} /(\mathrm{m} / \mathrm{s})]$, 粘性可変感度 $A=5[\mathrm{~N}]$, 摩擦

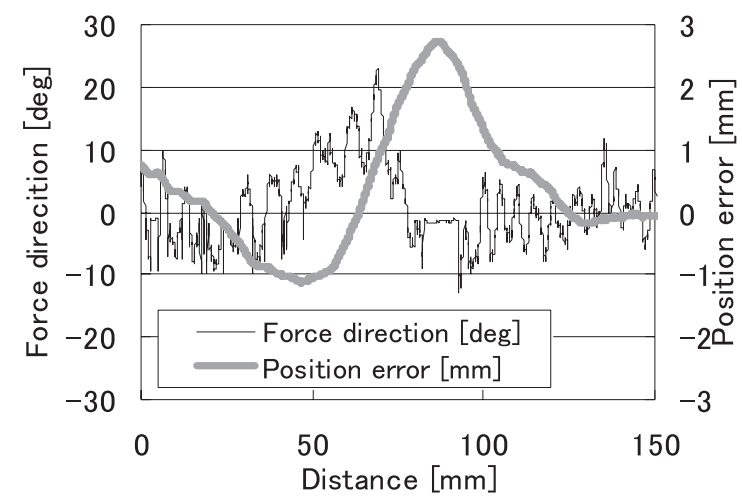

Fig. 5 Force direction \& position error of guide OFF 


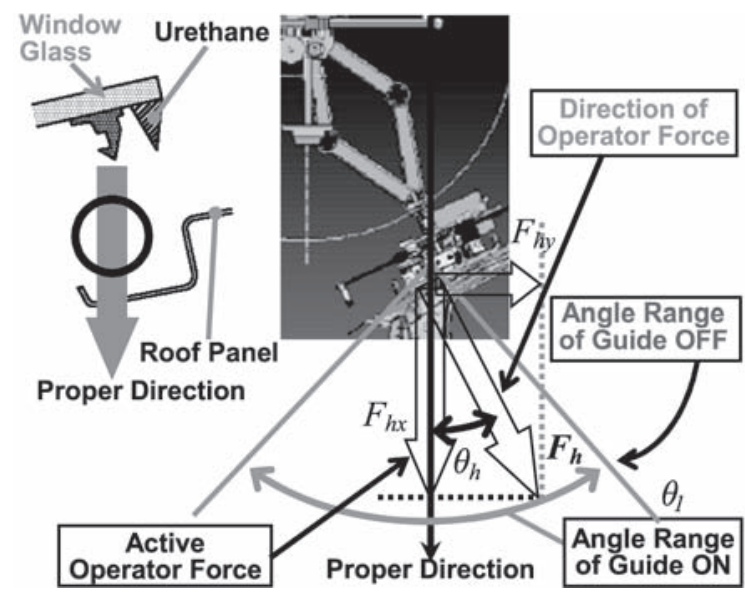

Fig. 6 Motion direction guide

力 $F=2[\mathrm{~N}]$ とした。 この結果を見ると，まっすぐ動かそうと するときには，操作力の向きはお抄む $\pm 20[\mathrm{deg}]$ 以内になっ ている（平均值 $0.65[\mathrm{deg}]$, 標準偏差 5.94 [dg] なので, およそ $\pm 3 \sigma$ に相当).このことより, 操作力の向きが真下方向に近い ときには，真下に降ろしたいという操作意図を判別できる可能 性を見出した

この知見に基づいて開発した「進行方向ガイド制御」と呼ぶ 技能支援技術を説明する。操作力の上下方向成分を $F_{h x}$, 前 後方向成分を $F_{h y}$ とする. Fig. 6 のように, 操作力の向き $\theta_{h}=\tan ^{-1}\left(F_{h y} / F_{h x}\right)$ がウインドウストッパの挿入向きに近い 角度範囲（例えば $\theta_{1}=20[\mathrm{deg}]$ ) 内のときには, 前後に位置決 めしたまままっすぐ下ろしたい操作意図と判断する。これによ り, 人の狙った前後位置に仮想のガイドが形成され，上下方向 には動きやすく，それ以外の向きには動きにくい特性を実現す る。操作力の向きがこの角度範囲外のときには, 位置調整をし たい操作意図と判断し, 操作力に基づいてガラスは進行する.

実際には，緩和区間を設け， $\theta_{1} \sim \theta_{2}$ (例えば $40[\mathrm{deg}]$ ) の間で 線形補間することとすると, 補正後の操作力前後方向成分は次 式のように表せる.

$$
\bar{F}_{h y}\left(\theta_{h}\right)= \begin{cases}0 & \text { if }\left|\theta_{h}\right| \leq\left|\theta_{1}\right| \\ F_{h y} \frac{\left|\theta_{h}\right|-\left|\theta_{1}\right|}{\left|\theta_{2}\right|-\left|\theta_{1}\right|} & \text { if }\left|\theta_{1}\right| \leq\left|\theta_{h}\right| \leq\left|\theta_{2}\right| \\ F_{h y} & \text { if }\left|\theta_{2}\right| \leq\left|\theta_{h}\right|\end{cases}
$$

この制御の効果を Fig. 7 に示す．仮想インピーダンス特性の 設定は先と同じである. 先のガイドなしの Fig. 5 では, 位置ズ レが最大で $2.7[\mathrm{~mm}]$ 程度であった。これに対しガイドありで は，操作力の向きはばらついているが，位置ズレは $\pm 0.5[\mathrm{~mm}]$ 以下であり，目標の前後位置決め精度を達成できた。

\section{3 量産ラインでの実作業}

開発したウィンドウ搭載アシストを用いた，実際の工場にお けるウィンドウ搭載作業の一連を Fig. 8 に示す。同図 (a) から, 作業者は両手をハンドルに添えて作業が開始される。 (a) から (c)までは，ほぼ自動的に誘導されていく（d)～(g)にかけて, 作業者は挿入位置を目視で確認し, 操作力による操作のみで進 路を修正しつつ挿入していく（h) で作業者による作業が完了 する，その後，自動的にガラスを押し付け，搭載が完了する.

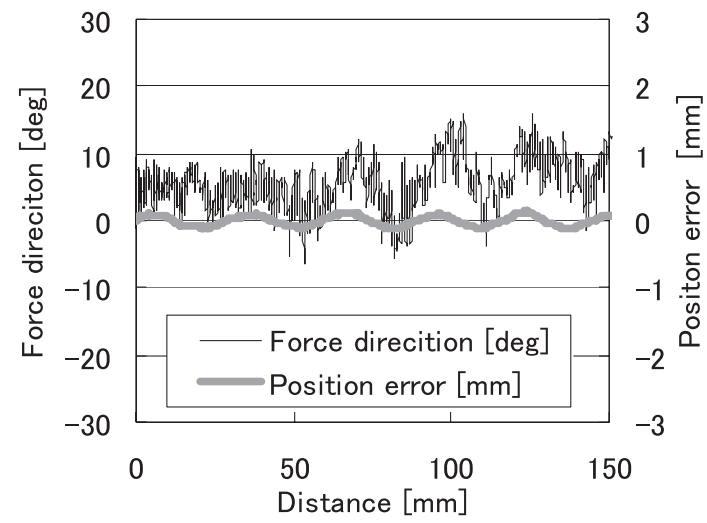

Fig. 7 Force direction \& position error of guide ON

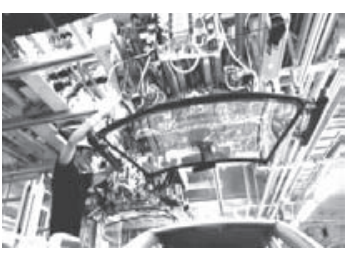

(a) $0.0[\mathrm{~s}]$

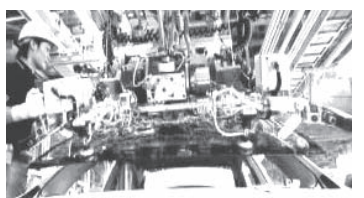

(c) $2.0[\mathrm{~s}]$

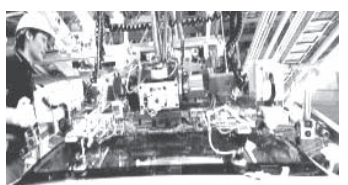

(e) $4.0[\mathrm{~s}]$

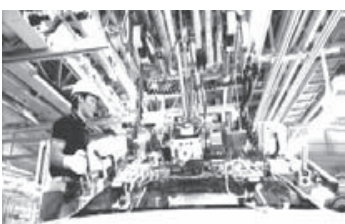

(g) $6.0[\mathrm{~s}]$

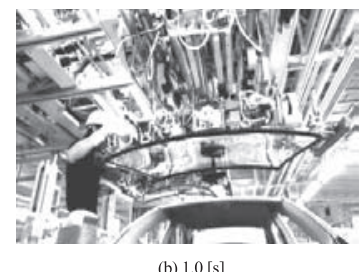

(b) 1.0 [s]

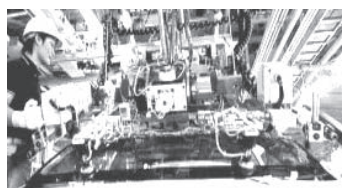

(d) $3.0[\mathrm{~s}]$

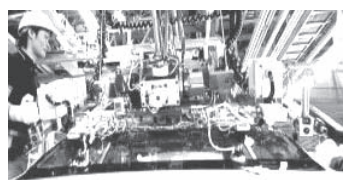

(f) $5.0[\mathrm{~s}]$

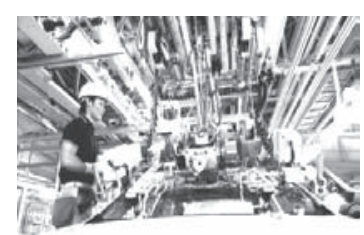

(h) $7.0[\mathrm{~s}]$
Fig. 8 Window installation with assist robot

このように，スイッチ操作することなく，操作力の向きによ り人の操作意図を判別するので，人がガイド制御を意識せずに， ロボットが位置合わせの技能を支援してくれる。 これにより，作 業時間が短縮され，品質も向上した。また，熟練期間は旧来の 二人作業では一ヶ月強かかっていたが, 本アシスト機では二週 間ほどに半減されたとの回答を得た。従来は，熟練したべテラ ンの屈強な男性作業者二人で担当していたが, 自動で押し付け ることができるようになり，アシスト制御で操作力も $30[\mathrm{~N}]$ 程 度まで低減されことと, 技能支援機能により, 現在では入社 3 ケ 月の新人の女性作業者一人でも担当できるようになった。 


\section{5. 結論}

本論文では, 最終的な品質は人が確認し, 機械が人と共存し て作業を支援する協働化という立場から開発・実用化したウィ ンドウ搭載アシストについて報告した。

（1）定格出力 $80[\mathrm{~W}]$ 以下の低出力モータで高推力を出せる 機構により, 人との共存, 接着剤押しつぶし品質, サイ クルタイム 48 秒を両立させた.

（2）挿入位置の要求精度 $\pm 2[\mathrm{~mm}]$ を達成するために，人の 手ぶれによる位置ズレを低減する，進行方向ガイド制御 を開発し，人が意識せずに人の技能を支援する技術を実 用化した。

（3）以上により，量産ラインにおいて，従来の二人作業から 片側一人作業を可能とするウィンドウ搭載アシストを実 用化した。

2007 年 8 月より, トヨタ自動車の量産ラインにて 2 台が稼 動を開始し, 昼夜 2 直体制で 2 年間稼動を続けている.

\section{6. 今後の展開}

人と協㗢するロボットの今後の展開としては, 大きく分けて 次の三つの方向性が考えられる.

第一に認識機能を発達させる方向性である，認識・センサ技 術の発展により位置決めを自動化する，また，ワークを作業者 の手元まで自動搬送することで, 人の作業時間をさらに短縮す る。 これらのグローバル展開には, 特に欧州で求められる ISO 規格に準拠することが求められる.

ISO 規格の準拠には, PL（Performance Level）[22] [24]の 安全認証を取得した人体検出センサや力・トルクセンサ, モー 夕と, これらを監視・演算する制御機器が必須であり, 各メー カーに協力を求めたい，また，先に 3.4 節で述べたように，国内 法規と ISO 規格が整合していないため，両方を満たそうとする と産業現場での実用性にそしい。 二つを整合させる上では, 産 業現場の実情を考慮した上での規格と法律の策定が望まれる。

第二にシンプル化・コストダウンの方向性である，省エネ，低 騒音化のため, 圧縮エアなしでの低出力駆動技術と, 高価な力 センサ，レーザセンサが不要なセンサレス制御を開発する。

第三は技能支援技術を発展させる方向性である。開発した技 能支援技術を, ウインドウの接着剤塗布などの軌跡精度が必要 な作業のダイレクトティーチングに応用する。 そして, 将来は, 固定型の設備から身につけるタイプのウェアラブルアシストに も展開する。これにより，車種変更などへ迅速に対応できる，メ ンテ工数の少ないフレキシブルな生産ラインを目指す.

謝 辞 実用機を製作いただいた（株）アラキ製作所の高柳 課長, 鈴木主任, 柴田主任, そして, ライン導入に御尽力いた だいた，藤原主幹をはじめとするトヨ夕自動車組立生技部の皆 様と, 高岡工場組立部第 12 組立課の現場作業者の皆様に感謝 致します。

\section{参 考 文 献}

[1] 䲨巣仁司, 荒木勇, 山田陽滋: “自動車組立作業支援装置スキルアシス トの実用化”, 日本ロボット学会誌, vol.22, no.4, pp.508-514, 2004.
[2] H. Kazerooni: "Human robot interaction via the transfer of power and information signals," IEEE Trans. on SMC, vol.20, no. 2 , pp.450-463, 1990.

[ 3 ] 福田敏男, 藤澤佳生, 新井史人, 室英治, 星野春夫, 宮崎貫志, 大坪 和彦，上原和雄： “マン・ロボット協調作業型マニピュレータの基礎的 研究 (第 1 報, マン・ロボット協調マニピュレータの機構と制御)”, 日本機械学会論文集 (C 編), vol.57, no.541, pp.2944-2952, 1991.

[4] 小菅一弘, 藤澤佳生, 福田敏男 : “仮想ツールダイナミクスに基づくマ ン・マシン系の制御”, 日本機械学会論文集 $(\mathrm{C}$ 編), vol.60, no.572, pp.1337-1343, 1993.

[5] M.A. Peshkin and J.E. Colgate: "Cobots," Industrial Robot, vol.26, no.5, pp.335-341, 1999.

[6] A. Bettini, P. Marayong, S. Lang, A.M. Okamura and G.D. Hager: "Vision-Assisted Control for Manipulation Using Virtual Fixtures," IEEE Trans. on Robotics, vol.20, no.6, pp.953-966, 2004.

[ 7 ] N. Takesue, R. Kikuuwe, A. Sano, H. Mochiyama and H. Fujimoto: "Tracking Assist System Using Virtual Friction Field," Proc. of IEEE/RSJ IROS'05, pp.2134-2139, 2005.

[8] R. Kikuuwe, N. Takesue and H. Fujimoto: "A Control Framework to Generate Nonenergy-Storing Virtual Fixtures: Use of Simulated Plasticity," IEEE Transactions on Robotics, vol.24, no.4, pp.781-793, 2008.

[9] T. Takubo, H. Arai, Y. Hayashibara and K. Tanie: "HumanRobot Cooperative Manipulation Using a Virtual Nonholonomic Constraint," International Journal of Robotics Research, vol.21, no.5, pp.541-553, 2002.

[10] Y. Hirata, Y. Kume, T. Sawada, Z.D. Wang and K. Kosuge: "Handling of an Object by Multiple Mobile Manipulators in Coordination based on Caster-like Dynamics," Proc. of the 2004 IEEE International Conference on Robotics and Automation, pp.807-812, 2004.

[11] O.M. Al-Jarrah and Y.F. Zheng: "Arm-Manipulator Coordination for Load Sharing Using Variable Compliance Control," Proc. of the 1997 IEEE Int. Conf. on Robotics and Automation, pp.895-900, 1997.

[12] R. Ikeura, A. Morita and K. Mizutani: "Variable damping characteristics in carrying an object by two humans," Proc. of 6th IEEE International Workshop on Robot and Human Communication, pp.130-134, 1997.

[13] M.M. Rahman, R. Ikeura and K. Mizutani: "Investigating the Impedance Characteristics of Human Arm for Development of Robots to Cooperate with Human Operators," Proc. IEEE Int. Conf. on Systems, Man, and Cybernetics, Tokyo, II, pp.676681, 1999.

[14] Y. Yamada, H. Konosu, T. Morizono and Y. Umetani: "Proposal of Skill-Assist: A System of Assisting Human Workers by Reflecting Their Skills in Positioning Tasks," Proc. IEEE Int. Conf. on Systems, Man, and Cybernetics, IV, pp.11-16, 1999.

[15] 武居直行, 菊植亮, 佐野明人, 望山洋, 澤田英明, 藤本英雄：“位置 決め作業アシストのための操作力依存可変ダンピング制御”, 日本ロ ボット学会誌, vol.25, no.2, pp.306-313, 2007.

[16] 中村久, 本田朋寞：“産業用パワーアシストシステム”, 計測と制御, vol.45, no.5, pp.445-448, 2006.

[17] N. Hogan: "Impedance Control Part 1 - Part 3," Trans. of ASME, Journal of Dynamic Systems, Measurement and Control, vol.107, pp.1-24, 1985.

[18] K. Kosuge, K. Furuta and T. Yokoyama: "Mechanical Impedance Control of a Robot Arm by Virtual Internal Model Following Controller," Proc. of IFAC 10th World Congress on Autonomous Control, vol.4, pp.250-255, 1987.

[19] 厚生労働省：リスクアセスメント等関連資料・教材一覧, 厚生労 働省労働基準情報ウェブサイト, http://www.mhlw.go.jp/bunya/ roudoukijun/anzeneisei14/

[20] 向殿, 安全技術応用研究会: 国際化時代の機械システム安全技術. pp.82-89, 日刊工業新聞社, 2000 .

[21] 中央労働災害防止協会: オンライン安全衛生情報 法令·通達告示・指針 
一覧, 安全衛生情報センターウェブサイト, http://www.jaish.gr.jp/ user/anzen/hor/horei01.html

[22] 向殿, 井上, 川池, 平尾, 逢原: 安全の国際規格 第 3 巻制御システ
厶の安全. pp.121-158, 日本規格協会, 2007.

[23] ISO10218-1:2006

[24] ISO13849-1:1999

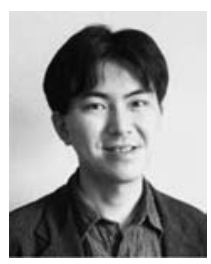

村山英之（Hideyuki Murayama）

1997 年東北大学大学院工学研究科修士課程修了. 1997 年より三菱電機（株）生産技術センターにて, 半導体と冷熱機器の組立·検査技術開発に従事. 2003 年よりトヨタ自動車 (株) 生技開発部, 2005 年よ りパートナーロボット部にて, パワーアシスト技術, 人の技能支援技術と人と協動する組立作業支援口 ボットの開発・実用化を行っている。

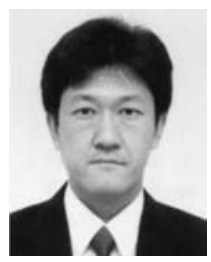

松本邦保 (Kuniyasu Matsumoto)

1992 年大阪大学基礎工学部機械工学科卒業. 1992 年よりファナック（株）にて産業用ロボットの開発 に従事. 2004 年よりトヨ夕自動車（株）生技開発 部, 2005 年よりパートナーロボット部にて, ヒュー マノイドロボット, 介護支援ロボットの開発・実用 化を行っている.

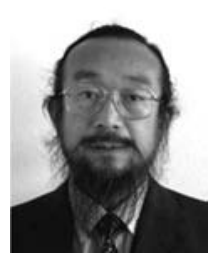

藤本英雄（Hideo Fujimoto）

1970 年名古屋大学工学部機械学科卒業. 現在, 名古 屋工業大学教授. 医学工学, 生産システム, ロボッ トなどの知能化，バーチャルリアリティ・感性の工 学に興味を持つ.JUFAS 最優秀論文賞, グッドデ ザイン賞など多数受賞. 名古屋工業大学ものづくり テクノセンター長, スケジューリング学会会長, 文 科省科学技術・学術審議会文化資源委員会委員など歴任. 現在, 愛知 県ものづくり人材育成協議会座長, 日本機械学会フェロー・評議員. 工学博士.

（日本ロボット学会正会員）

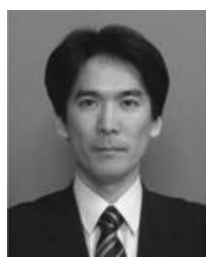

武居直行（Naoyuki Takesue）

2000 年大阪大学大学院工学研究科電子制御機械工 学専攻博士後期課程修了. 2000 年大阪大学助手. 2003 年名古屋工業大学寄附講座講師. その後, 准 教授を経て, 2008 年首都大学東京准教授. 博士 (工 学)、ロボットの運動制御, 触覚テクノロジー, 人 間・機械系などの研究に従事. 2004 年日本ロボッ 卜学会研究奨励賞受賞. 日本機械学会, 計測自動制御学会, 電気学会, 精密工学会, IEEE の会員.

（日本ロボット学会正会員）

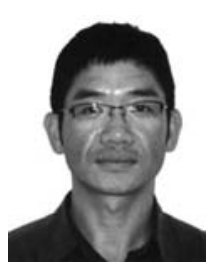

\section{鴻巣仁司 (Hitoshi Konosu)}

1986 年トヨ夕自動車株式会社入社. 1999 年豊田 工業大学大学院修士課程修了. 現在, 卜ヨ夕自動 車パートナーロボット部に勤務. パワーアシストロ ボットの開発に従事. 2002 年日本ロボット学会第 7 回実用化技術賞受賞。（日本ロボット学会正会員） 